\title{
LXI. Proposal for a new method of determining a fixed unit of measure, by deducing the same from the curvature of the earth
}

James Boaz Esq.

To cite this article: James Boaz Esq. (1823) LXI. Proposal for a new method of determining a fixed unit of measure, by deducing the same from the curvature of the earth, Philosophical Magazine Series 1, 61:300, 266-269, DOI: 10.1080/14786442308644321

To link to this article: http://dx.doi.org/10.1080/14786442308644321

电 Published online: 27 Jul 2009.

Submit your article to this journal $\pi$

Џll Article views: 3

Q View related articles $\sqsubset$ 
rock of our own soil, instead of deflagrating the woods of America. As a proof of this, I instanced the production of the three alkalies from the same substance by animalization.

After many a varied experiment I have completely succeeded; and have now rendered myself and my country, so far as regards bleaching, perfectly independent of every foreign aid, and at an expense comparatively trifling. Neither pot- nor pearl-ashes are any longer indispensables, - a truly British substance can be substituted in their stead with equal safety and effect.

I am satisfied this will apologize for my seeming neglect.

$$
\text { I remain yours truly, }
$$

Strathinday Bleachfield, April 8, 1823.

Gavin Inimis.

I recollect the circumstances stated by $\mathrm{Mr}$. Inglis in the above letter. I did not conceive myself at liberty to mention them to any one, and much less to publish them. I hope, however, that Mr. I. will ere long forward some details calculated to satisfy that inquisitive curiosity which his letter must excite in all who read it.-A. T.

LXI. Proposal for a new Method of determining a Fixed Unit of Measure, by deducing the same from the Curvature of the Earth. By JAMEs BoAz, Esq. of Glasgore.

SIR,

To Captain Henry Kater, F.R.S.

FROM the indefatigable zeal and perseverance shown by you in endeavouring to ascertain the true length of the pendulum vibrating seconds, as a standard of measure, $I$ can think of no person than you better qualified to estimate the value of the suggestion in the inclosed communication, and to give it efficacy, should it seem to merit any further notice. It was read by me before the Glasgow Philosophical Society on the 17th of December 1821.

I have the honour to be

Your obedient humble servant,

Glasgow, March 21, 1823.

J AMrs BoAz, Accountant.

A fixed standard of weights and measures has for many years been much sought after, - one that will remain the same in all ages, and which, even although destroyed, and no vestige of it, or of any former standard, were in existence, could be formed anew at any time, and in any country. An universal unit measure of length once got, measures of greater or lesser lengths, capacities and weights could easily be formed therefrom. 
Lineal measures in former times were often taken from very uncertain materials:- a hair's breadth, a barleycorn, a thumb's breadth, a hand's breadth, a span, a foot, a cubit, a fathom, \&c., were all liable to much dissimilarity and variation.

In traversing nature and art, every species of matter tends to alteration and decay. The heights of mountains and peaks are lessened, as well by the gradual disintegration and disruption of their parts, as by the filling up of their conterminous valleys. The pyramids of Egypt are in the same situation. Stone, wood, earth, glass, are liable to change and destruction. Metals oxidize, wear, expand, contract, and are subject to a thousand accidents and uncertainties. In a word, every thing on the earth is in a state of continual mutation and decomposition.

Time, for aught we know to the contrary, is unerring. The planets like the earth are in continual circulation at various vast velocities round the centre of their orbits, the sun. We can measure their periodical times; we can measure our own; we know with almost perfect accuracy the number of seconds the earth takes to perform her annual journey round the sun. It is upon this principle that perdulums, beating true sidereal seconds at a certain latitude, measure 39 inches and a fraction: but does this proposed standard of lineal measure leave nothing further to be desired?

The French, reasoning on the earth itself being subject to no increase or decrease of bulk, attempted to measure one of its degrees, and therefrom deduce an unchangeable unit of measure; but their scheme being on such an extensive scale, performed at so many operations, different times, and by so many persons, was liable to errors in nearly a corresponding proportion.

The scheme by which I propose, with much deference, to find a fixed unit of measure, is founded on the unchangeable and uniform convexity of the earth, the result of the general law of gravitation.

In order to make myself completely understood, I shall here quote a passage from some MS. miscellaneous essays written by me a number of years ago.- " Level. That curve or convexity which the surface of water at rest assumes, amounting to very nearly 8 inches under the apparent level or straight line, in 1 mile; 32 inches in 2 miles; 72 in 3 miles: 128 in 4. miles; 199 in 5 miles; 796 in ten miles; and so on increasing in the ratio of $1,4,9,16,25, \& c$.; that is, as the square of the distance. See the Earth."--Here follow various tables and rules for finding the dip necessary in cutting any number of yards or miles of canals, \&c. 
To take advantage of this spherical curvature for my present purpose, lay level, at the level of the sea, in a straight line, due east and west, say one mile of cast-iron inch pipe; let each end have a knee bending upwards, terminating above ground in a faucette or locket, into each of which cement a glass tube: these tubes for distinction's sake I call A and B; "fill the whole length of pipe with some homogeneous fluid, say water, until it rises a few inches in the said tubes. Place a straight piece of brass about 36 inches long, truly level, at the same height as the surface of the water in tube $A$. In looking along this straight edge, or by means of a level micrometered telescope, the line of vision will lead, not to the surface of the water in the distant tube B, but 8 inches higher up. This experiment will prove, that the amount of the earth's convexity in. 1 mile is 8 inches; were the pipe to be 2 miles long, the convexity would be 32 inches; 3 miles, 72 inches; 4 miles, 128 inches; 5 miles, 199 inches; 10 miles, 796 inches, and so on: any of these inch numbers may be adopted as the unit. I would prefer the 72 .

In 1 mile, the unit of 8 inches is found 7920 times.

In 2 miles, the unit of 32 inches is found 3960 times.

In 3 miles, the unit of 72 inches is found 2640 times.

In 4 miles, the unit of 128 inches is found 1980 times.

In 5 miles, the unit of 199 inches is found 1592 times.

In 10 miles, the unit of 796 inches is found 796 times.

It is a curious coincidence, that the earth's convexity in 10 miles or 633,600 inches is $66 \frac{1}{3}$ feet, or 796 inches : were this last number adopted as the unit, there would be just 796 of them in the 10 miles; in other words, the convexity is a 796th part of that lineal distance.

\section{How to reproduce the Unit, if lost.}

Suppose a person were to be deprived of all kinds of measures whatever; how could he without them find out the exact length of 6 feet, and the exact distance of 3 miles? Answer : He would first lay his pipe as near to 3 miles as possible: This he could approximate, by making for himself a wooden fathom measure or rod the length of his outstretched arms. To prove its correctness, he would place it vertically just above the surface of the water in $B$, to see if from $A$, at the distance of 2640 of these approximated fathoms, his straight line of vision led exactly to the upper end or top of the rod under examination. If it led above its top, then he might be certain that what he had considered as 3 miles was actually more: he would therefore shorten his rod, and measure 2640 lengths of it again. 
On the second trial, if his line of vision led below its top, then what he had last measured as 3 miles was actually less: this would cause him to lengthen his rod, which for the second trial he had shortened too much, and measure again; and thus would he go on approximating, until at the distance of 2640 lengths of his rod his line of vision led exactly to the top of it; when he might rest assured that its length was correcly 1 fathom, being the unit sought, and the distance 3 miles; for no other number of lengths will tally with the curvature at the same distance. To illustrate this doctrine, I shall suppose that at the first trial, his rod, instead of being 72 inches, as it ought, was 74; ; 2640 lengths of it made the distance 5427 yards, at which the straight line of vision would lead to nearly 2 inches above the top of his rod. At the second trial his rod instead of being 72 inches was only $70 ; 2640$ lengths of it made the distance 5133 yards, at which the straight line of vision would lead to more than 2 inches below the top of his rod.

This reciprocal self check of the standard can therefore be made at any time with perfect mathematical accuracy. Its principle depends on the difference of angular convexity between the surface of the water and the straight line of vision, increasing, as it does, in a certain geometrical ratio; while the lineal distance for ascertaining it increases in only an arithmetical ratio.

I have assumed the above spherical convexity as true: when tried in the way proposed, it may perhaps be found a trifle different; but its exact amount will then be accurately ascertained, as may also the true diameter, circumference and shape of the earth.

To make the cast-iron pipe just 3 miles long, could be effected without a measure by other methods; such as, 1st, with two transit instruments, to note the space that the earth revolved on its axis from west to east, in (say) 5 seconds of time; 2d, by noting the space that sound travelled, in(say) 14 seconds of time. But I humbly think, that the method I have above suggested, containing as it does within itself a complete check on, and a proof of the result, is the most preferable, simple, and least liable to error.

The subdivisions of this fathom unit into universal measures of length, capacity, and weight, may be the subject of a future essay.

Glasgow, March 1, 1823.

J. Bosz.

LXII. $O n$ 